\title{
MECHANICAL ANALYSIS PROCESS OF A COAXIAL COUNTER ROTOR FOR APPLICATIONS IN UNMANNED ULTRA-LIGHT UNITS
}

\author{
Łukasz Czajkowski \\ Institute of Aviation, \\ Al. Krakowska 110/114, 02-256 Warsaw, Poland \\ lukasz.czajkowski@ilot.edu.pl
}

\begin{abstract}
As the rotor configuration has the most impact on helicopter properties, the process of determination the assumptions for rotor design is a very important factor in the early stage of rotorcraft development. The following paper presents a mechanical analysis process used at the Institute of Aviation to quickly develop a coaxial rotor prototype applicable in ultra-light unmanned helicopter which has the potential for further improvement of its flight parameters. The article describes the rotor analysis process due to its feasibility based on commercially available solutions, the process of formulating assumptions for the entire structure, MES analysis of the rotor parts all leading to creation of the rotor prototype.
\end{abstract}

Keywords: rotor analysis, coaxial rotor, ultra-light.

\section{INTRODUCTION}

Before starting any construction work on a new helicopter solution, it is necessary to comprehensively analyze the character of work to which the designed unit will be subject. Parameters such as maximum take-off weight, maximum payload, operating range, maximum flight speed, economy of maintenance and operation, market trends, manufacturing technology or the type of power supply should be taken into consideration. The designer should realize that maximizing all of these factors simultaneously is impossible therefore it is very important to determine correctly the designation of the helicopter at a very early stage of project.

The most important part of helicopter structure is rotor system which generates forces providing lift, drag overcoming as well moments for helicopter control. Comparing helicopter with fixed wing aircraft, it can be noticed that rotor fulfills role of wing, propeller and control surfaces like ailerons or rudder in case of multi rotor units. Helicopters are controlled due to changes of collective and cyclic 
pitch of rotor blades. In the case of single main rotor configuration the tail rotor is applied for directional stability and control.

The factor that influences the parameters of a given helicopter the most is the kind of applied rotor system. Due to the fact that the rotating rotor generates a rotary torque (opposite to its rotation) acting on a helicopter, it is necessary to introduce the element which counteracts this moment. In nowadays solutions there are rotor systems used to a greater or lesser extent due to their advantages in a specific application.

- Single-rotor system with tail rotor: simple construction, light rotor hub, simple main transmission, low cost of manufacturing, a large knowledge base based on existing solutions, power loss on tail rotor, necessity of using a tail rotor gearbox, long tail boom increasing the dimensions of the helicopter.

- Dual rotor with longitudinal placement: good longitudinal stability, good weight efficiency, a large hull volume (large users capacity), complicated drive train, large induced drag if forward flight, necessity of reliable synchronization of rotors rotation, complicated landing from the autorotation flight.

- Dual rotor with transverse placement: good maneuverability and sufficient longitudinal and transverse stability, smaller than in other systems the drag induced in forward flight due to the positive mutual influence of the rotors, which implies greater economy and increase of range, good conditions for the comfort of the crew and passengers when using two engines and elevating them to the sides of the hull, complicated construction, complicated control devices, necessity of reliable synchronization of rotors, especially in case of their obscuring.

- A two-rotor system with intermeshing rotors: relatively low face drag due to the short streamlined hull, small external dimensions, necessity of reliable synchronization of rotors, complicated drive train, Threat to people's safety and the possibility of hooking the ground with the ends of the blades.

- Multi rotor system with three or more rotors: good stability and steerability, the same type of blades and hubs in all rotors, complicated and heavy construction (using a mechanical torque transmission system), large frontal drag, complicated control system, large external dimensions.

- Jet rotor system: no complicated power transmission, high operational reliability, fewer centers for forces that cause vibrations, low manufacturing costs, high load efficiency, high fuel consumption, complicated construction of special engines, aimed at ensuring normal operation in the field of centrifugal forces at the ends of the blades, strong noise of jet and pulse jet engines.

- Gyro system with driven rotor and a forward propulsion system: high cruising speed, possibility of autorotation flight, high energy efficiency system during fast forward flight, complicated mechanical transmission system for the rotor and propellers

- Tiltrotor system: high cruising speed.

- Gyrocopter system with non-driven rotor and a forward propulsion system: high cruising speed, low fuel consumption, need of airfield.

- Coaxial rotor system: relatively low face drag due to the short, properly shaped hull, small external dimensions, no tail rotor, increased load factor from 1 kilowatt of power, reduced diameter of the rotor, a small asymmetry of the lift force in the forward motion, simpler control due to aerodynamic forces, more stable flight, better stability in hover due to contrary side reactions of rotors in case of wind gusts [2], complicated control devices and complicated power transmission, harmful interaction of both rotors, insufficient directional stability, danger of collision of the blades of both rotors. 


\section{DESIGN ASSUMPTIONS}

This article discusses the design process applied to the coaxial rotor designed at the Institute of Aviation and the assumptions made before the whole process. The aim of the project was to develop an unmanned aircraft with the possibility of vertical takeoff and landing, while maximizing its cruising speed and payload, without exceeding the regulations of the ultra-light class (up to $450 \mathrm{~kg}$ of take-off mass).

On the basis of the advantages and disadvantages of the above-mentioned systems, a dual coaxial rotor has been selected which has a higher thrust generation factor from a unit of power and a small asymmetry of lift in level flight making it an ideal base for designing a high cruising speed helicopter.

The rotor hubs will be rigid to minimize the distance between them, what is not possible with a fully articulated rotor head due to the flap hinge.

\subsection{Market analysis}

An important aspect of the work should be the analysis of the market for the designed helicopter to fit into a niche that is not filled with commercially available solutions. On the basis of analyzes of available helicopter solutions for unmanned drones, a summary is presented (Tab. 1.).

Table 1. Helicopter drones summary [5-19].

\begin{tabular}{|l|c|c|c|c|c|c|}
\hline Name & Power & Takeoff mass & $\begin{array}{c}\text { Useful } \\
\text { load }\end{array}$ & Length & $\begin{array}{c}\text { Operational } \\
\text { time }\end{array}$ & Max speed \\
\hline $\begin{array}{l}\text { Skeldar } \\
\text { V-150 }\end{array}$ & $41 \mathrm{~kW}$ & $150 \mathrm{~kg}$ & $55 \mathrm{~kg}$ & $4 \mathrm{~m}$ & $4-6 \mathrm{~h}$ & $100 \mathrm{~km} / \mathrm{h}$ \\
\hline $\begin{array}{l}\text { Sikorsky } \\
\text { Cypher II } \\
- \text { Dragon } \\
\text { Warrior }\end{array}$ & $37 \mathrm{~kW}$ & $154 \mathrm{~kg}$ & $20 \mathrm{~kg}$ & $1,88 \mathrm{~m}$ & $2-3 \mathrm{~h}$ & $97 \mathrm{~km} / \mathrm{h}$ \\
\hline ASV - 100B & $11 \mathrm{~kW}$ & $59 \mathrm{~kg}$ & $25 \mathrm{~kg}$ & $\begin{array}{c}\text { No data avail- } \\
\text { able }\end{array}$ & $2-3 \mathrm{~h}$ & No data available \\
\hline EADS Sharc & $37 \mathrm{~kW}$ & $190 \mathrm{~kg}$ & $60 \mathrm{~kg}$ & $2,5 \mathrm{~m}$ & $3-4 \mathrm{~h}$ & No data available \\
\hline SDO $50 \mathrm{~V} 2$ & $11 \mathrm{~kW}$ & $87 \mathrm{~kg}$ & $45 \mathrm{~kg}$ & $2,32 \mathrm{~m}$ & $3-4 \mathrm{~h}$ & $10 \mathrm{~km} / \mathrm{h}$ \\
\hline Koax X-240 & $8 \mathrm{~kW}$ & $45 \mathrm{~kg}$ & $8 \mathrm{~kg}$ & $1,65 \mathrm{~m}$ & $1-1,5 \mathrm{~h}$ & $80 \mathrm{~km} / \mathrm{h}$ \\
\hline $\begin{array}{l}\text { Skeldar } \\
\text { V-200 }\end{array}$ & $58 \mathrm{~kW}$ & $235 \mathrm{~kg}$ & $40 \mathrm{~kg}$ & $5,2 \mathrm{~m}$ & $5-6 \mathrm{~h}$ & $140 \mathrm{~km} / \mathrm{h}$ \\
\hline $\begin{array}{l}\text { Camcopter } \\
\text { S-100 }\end{array}$ & $40,4 \mathrm{~kW}$ & $200 \mathrm{~kg}$ & $50 \mathrm{~kg}$ & $3,9 \mathrm{~m}$ & $5-6 \mathrm{~h}$ & $220 \mathrm{~km} / \mathrm{h}$ \\
\hline Ehang 184 & $106 \mathrm{~kW}$ & $300 \mathrm{~kg}$ & $100 \mathrm{~kg}$ & $3,9 \mathrm{~m}$ & $23 \mathrm{~min}$ & $100 \mathrm{~km} / \mathrm{h}$ \\
\hline SVU-200 & $47,7 \mathrm{~kW}$ & $360 \mathrm{~kg}$ & $120 \mathrm{~kg}$ & $5,2 \mathrm{~m}$ & $2-2,6 \mathrm{~h}$ & $255 \mathrm{~km} / \mathrm{h}$ \\
\hline Ka - 137 & $50 \mathrm{~kW}$ & $280 \mathrm{~kg}$ & $80 \mathrm{~kg}$ & $5,3 \mathrm{~m}$ & $3-4 \mathrm{~h}$ & $175 \mathrm{~km} / \mathrm{h}$ \\
\hline Ka-37 & $45 \mathrm{~kW}$ & $250 \mathrm{~kg}$ & $50 \mathrm{~kg}$ & $4,8 \mathrm{~m}$ & $1 \mathrm{~h}$ & $175 \mathrm{~km} / \mathrm{h}$ \\
\hline TD 220 & $48 \mathrm{~kW}$ & $290 \mathrm{~kg}$ & $100 \mathrm{~kg}$ & $3,9 \mathrm{~m}$ & $4-5 \mathrm{~h}$ & $100 \mathrm{~km} / \mathrm{h}$ \\
\hline
\end{tabular}

From the list it can be seen that the helicopter should have a useful mass exceeding $120 \mathrm{~kg}$ with a maximum starting mass not exceeding $450 \mathrm{~kg}$ and a top speed above $255 \mathrm{~km} / \mathrm{h}$. 


\subsection{Drive unit}

In order to ensure the potential use of the rotor, the starting point for the analysis is to choose a drive unit that could be used with it and is commercially available. The most important criterion of the engine is the power generated from one unit of mass. Turbine units have the best ratio, but in order to ensure the feasibility of assumptions, it is necessary to rely on piston units available commonly on the market because they are much cheaper than turbines and more economic (from the side of fuel consumption). On top of that they are much easier to buy than turbine engines because they have more resellers in Europe. Electrical engines are overlooked because this solution is designed to be fuel powered. Another important parameter is the torque of the engine which should ensure continuous operation of the unit at the maximum helicopter's flight control (maximum thrust). The following is a summary of the aviation engines available on the market (Fig. 1.).

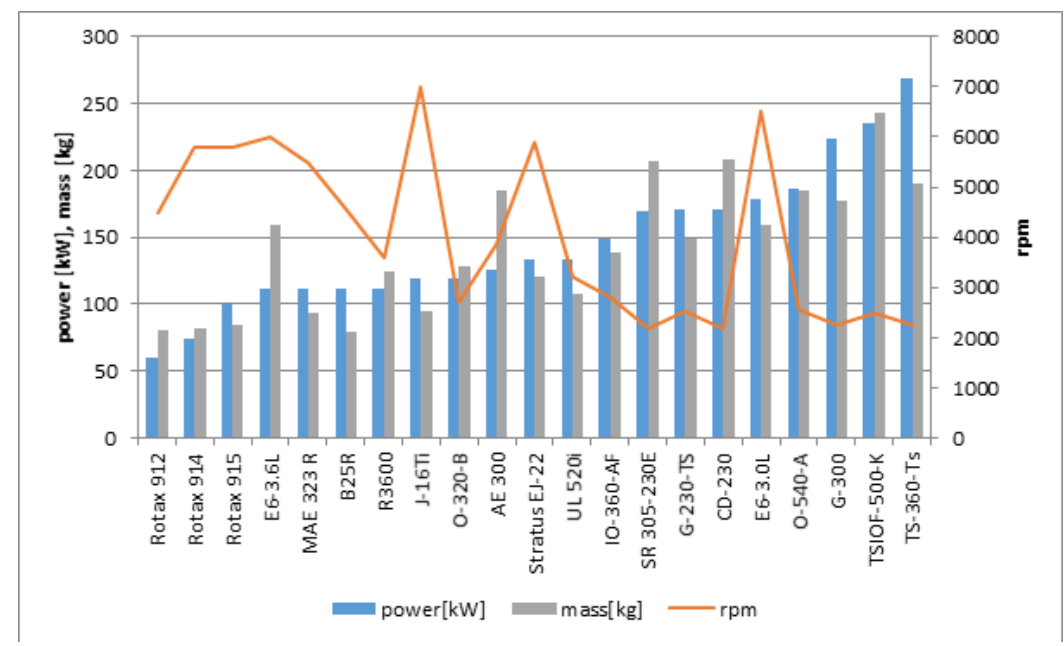

Figure 1. Commercial engines comparison [Own elaboration]

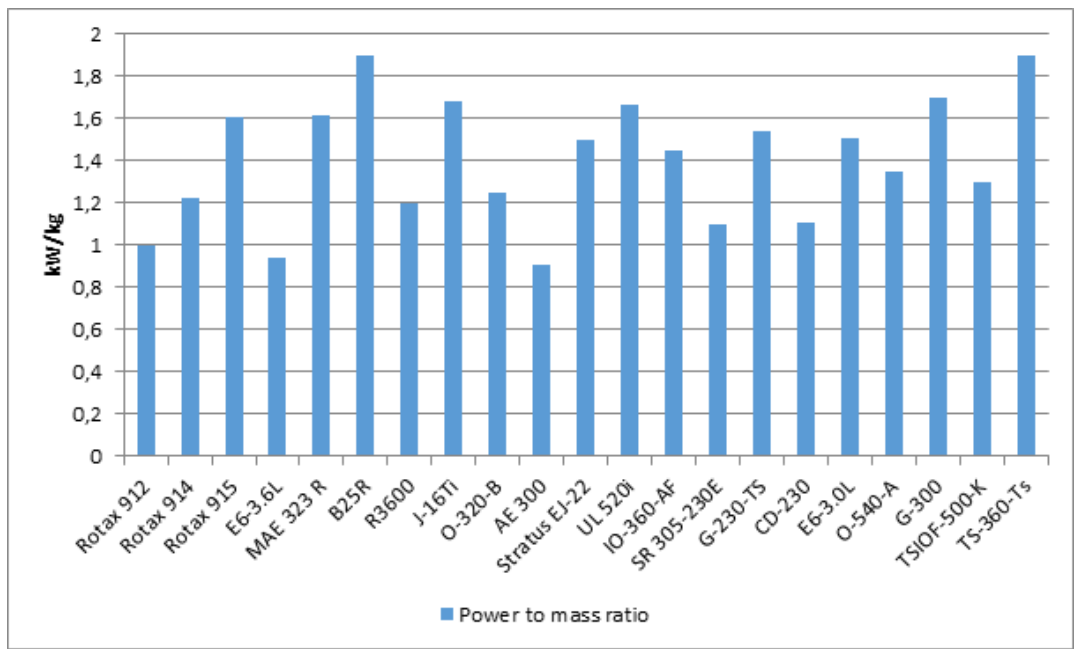

Figure 2. Power to mass ratio [Own elaboration] 
In order to estimate the power demand of the entire system, analysis of helicopters in the ultra-light class was carried out.

Table 2. Comparison of engines used on ultra-light helicopters [Own elaboration]

\begin{tabular}{|l|c|c|c|}
\hline Name & Takeoff mass & Engine name & Engine power \\
\hline DF Helicopters DF334 & $500 \mathrm{~kg}$ & Rotax 914 & $85 \mathrm{~kW}$ \\
\hline Heli-Sport CH-7 & $450 \mathrm{~kg}$ & Rotax 914 & $84 \mathrm{~kW}$ \\
\hline Aerokopter AK1-3 Sanka & $650 \mathrm{~kg}$ & Subaru EJ25 & $116 \mathrm{~kW}$ \\
\hline Mosquito Aviation XE & $277 \mathrm{~kg}$ & Zanzottera MZ 202 & $47 \mathrm{~kW}$ \\
\hline Dynali H3 EasyFlyer & $500 \mathrm{~kg}$ & Rotax 912 & $74 \mathrm{~kW}$ \\
\hline RotorWay Exec & $680 \mathrm{~kg}$ & RotorWay RI $162 \mathrm{~F}$ & $111 \mathrm{~kW}$ \\
\hline Revolution Mini-500 & $372 \mathrm{~kg}$ & Rotax 582 & $47 \mathrm{~kW}$ \\
\hline Curti Zefhir & $699 \mathrm{~kg}$ & TS100 turboshaft & $105 \mathrm{~kW}$ \\
\hline LCA LH 212 Delta & $450 \mathrm{~kg}$ & Rotax 914 & $84 \mathrm{~kW}$ \\
\hline Hungaro Copter & $430 \mathrm{~kg}$ & Subaru EJ22 & $100 \mathrm{~kW}$ \\
\hline Youngcopter Neo & $640 \mathrm{~kg}$ & Neosis twin-rotor & $134 \mathrm{~kW}$ \\
\hline Eagle Helicycle & $386 \mathrm{~kg}$ & Solar T62-T32 turboshaft & $111 \mathrm{~kW}$ \\
\hline Konner K1 & $450 \mathrm{~kg}$ & Konner TK-250 turboshaft & $186 \mathrm{~kW}$ \\
\hline Millennium MH-1 & $499 \mathrm{~kg}$ & Yamaha & $96 \mathrm{~kW}$ \\
\hline
\end{tabular}

Table 3. Comparison of mentioned helicopters from Table 1 and Table 2 [Own elaboration]

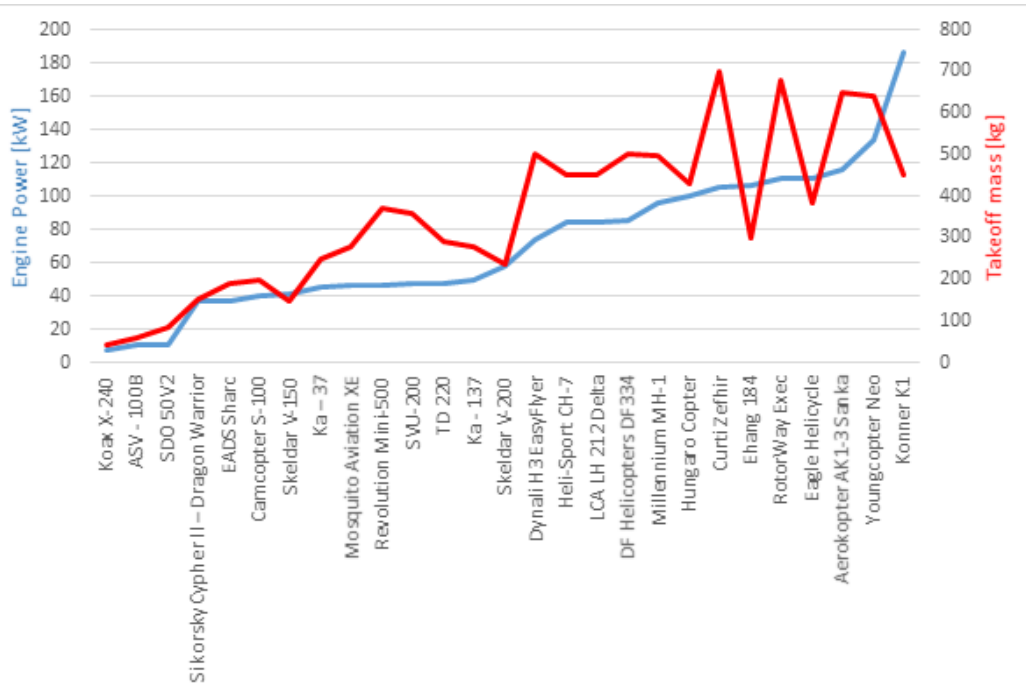

All analyzed ultra-light helicopters are equipped with a single rotor system with a tail rotor. Due to the fact that part of the power in such an arrangement is consumed by the tail rotor, it can be concluded that the coaxial rotor will create a lifting force of $450 \mathrm{~kg}$ using about 100 horsepower of the engine power. 


\subsection{Aerodynamic analysis results}

The drag and lift force were calculated in a hover state in such manner that the blade was divided in segments that are moving with different speeds depending on what radius of the rotor disk each segment is placed. The sum of drag for each segment generates the blade power consumption and the sum of lift force for each segment generates the blade lift force. Taking into consideration that in the coaxial system one rotor affects the other the bottom rotor lift force was reduced by $20 \%$ and the drag was increased by $20 \%$. The airfoil length was set to $150[\mathrm{~mm}$ ] because of the manufacturing capabilities for the composite rotor blades. The diameter of the rotor was calculated using iterations which were increasing the rotor diameter till it achieved about $450[\mathrm{~kg}]$ or thrust.

The geometrical blade twist were determinated for each segment using the following:

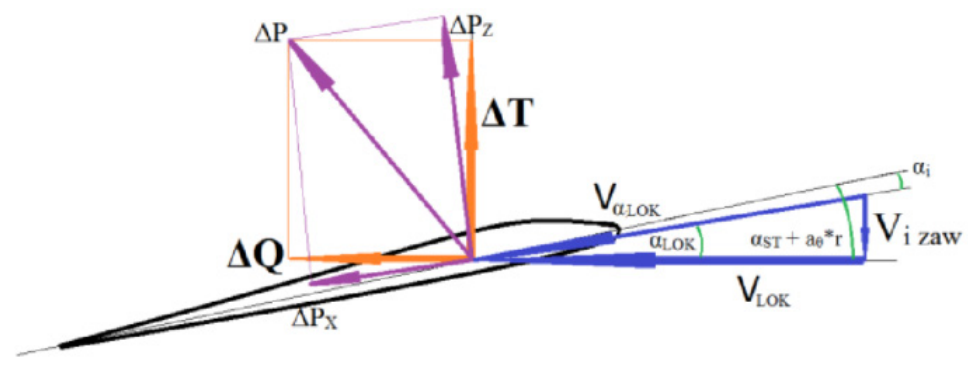

Figure 3. Distribution of forces and velocity vectors on profile [21]

Induced hover velocity can be calculated according to (1) [21]

$$
\mathrm{Vi}_{\text {hover }}=\sqrt{\frac{\mathrm{m} * \mathrm{~g}}{2 * \rho * \mathrm{~A}_{\mathrm{d}}}}
$$

Where:

$m-$ mass of helicopter, $\rho$ - atmosphere density, $A_{d}-$ main rotor disc area

The calculation results are as follows:

Rotor diameter: 4.5 [m];

Blade airfoil type: ILHX4a1-12 m1;

Collective pitch max: 17 [deg];

Rotor rpm: 550 [rpm];

Number of blades: 6;

Power consumed: 60,19 [hp];

Thrust generated: $451,16[\mathrm{~kg}]$;

Geometrical blade twist: $-6,5[\mathrm{deg}]$;

Based on chapter 2.2 the power requirement for a helicopter with a standard single rotor with tail rotor configuration needs about 100 [hp] for generating about 450 [kg] of lift mass, the aerodynamic calculations show that the coaxial rotor will need less power to achieve that lift mass.

On the basis of the comparison in table 2 and set of defined assumptions the choice of engine type, which will be used for further structural and theoretical analyzes, was possible. The choice fell on the widely available ROTAX 912 aircraft engine power 80 [hp]; torque 104 [Nm]; revolutions up to 5,800 [rpm]. 


\section{MECHANICAL DESIGN}

Having all the necessary data obtained in the process of formulating construction assumptions, the final mechanical design of the coaxial rotor can be started.

\subsection{Rotor blades}

Based on previous aerodynamic analyzes, the geometrical parameters of the blade were determined:

- Total length of the blade: $2200[\mathrm{~mm}]$;

- Airfoil length: 150 [mm];

- Airfoil type: ILHX4a1-12 m1;

- Geometrical blade twist -6,5 [deg]

Due to the fact that the rotors rotate in opposite directions, it is necessary to develop right and left rotary blades with the mentioned parameters.

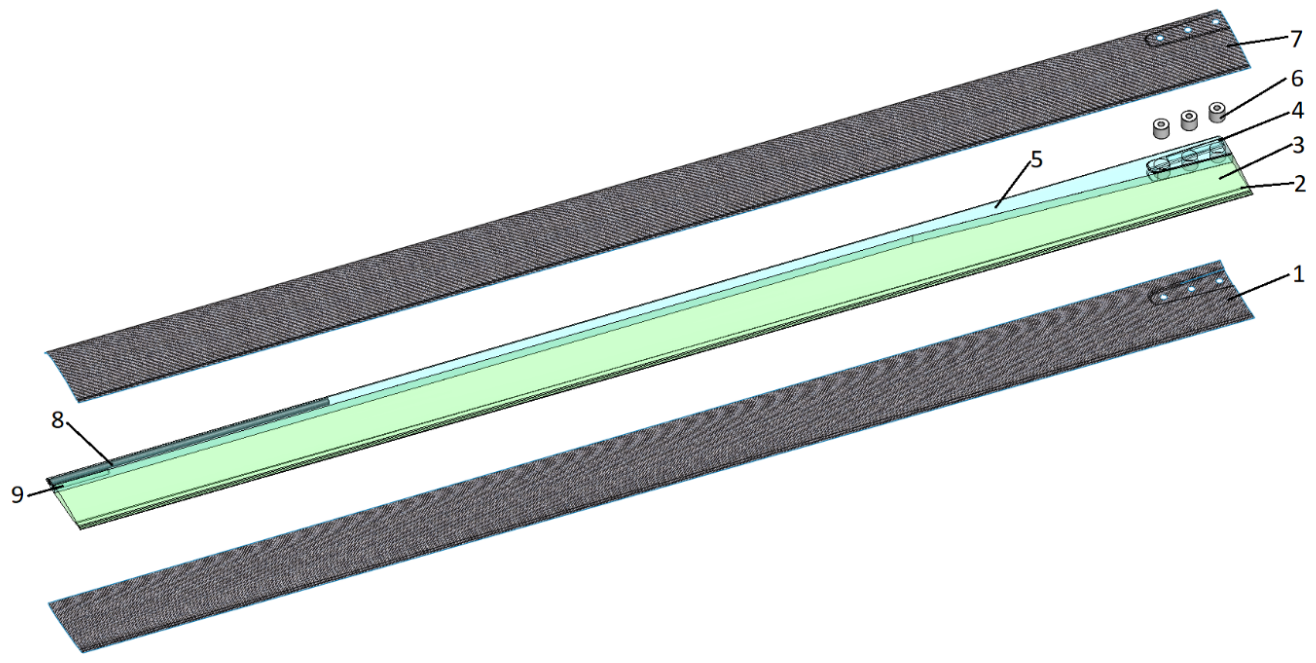

Figure 4. Construction of a composite blade; 1-bottom cover made of carbon composite; 2-ventilation channel; 3-expanding resin; 4-balancing chamber; 5-carbon roving girder; 6-duralumin mounting sleeves; 7-top cover made of carbon composite; 8-anti flutter mass; 9-balancing chamber [Own elaboration]

Blade manufacturing technology is based on composite materials. The outer cover consists of two upper and lower layers (Fig. 4. \{1;7\}) made of Toray T300 carbon composite. The cover consists of four layers of symmetrical fabric laid at an angle of $45^{\circ}$, which ensures high resistance of the blade to torsion. The blade girder (Fig. 4. \{5\}) is made of Toray T700 carbon roving braided around duralumin clamping sleeves (Fig. 4. \{6\}) which task is to transfer forces from the girder to the rotor head fastening elements. In order to shift the center of gravity of the blade (to prevent self-excited vibrations the socalled flutter) on the tip of the blade there is a antiflutter mass (Fig. 4. $\{8\}$ ) in the form of a steel rod laminated into the girder. At both ends of the blade (Fig. 4. \{4;9\}) there are balancing chambers for 
modifying the position of the center of gravity along the length of the blade in the balancing process, which takes place by changing the mass of weights placed in the chambers. The blade is filled with an expanding resin (Fig. 4. \{3\}) which increases its stiffness in the plane of small stiffness. Inside the filling there is a ventilation channel (Fig. 4. \{2\}) for draining moisture from the blade. The blade is covered with a special polyurethane paint that has anti-erosive properties that increase abrasion resistance. Applying the construction materials parameters to each of the model part gave the overall mass of the blade at about $6 \mathrm{~kg}$.

\subsection{Main transmission}

The selected motor generates a torque of approximately $104[\mathrm{Nm}]$ and revolutions in the range of $4500-5000[\mathrm{rpm}]$. The engine is equipped with a reducer (1:2.43), therefore the output has a maximum torque of $\mathbf{2 5 2 . 7 2}[\mathrm{Nm}]$ and a rotational speed of $\mathbf{1 8 5 2 - 2 0 5 8}[\mathrm{rpm}]$. In order to achieve the assumed rotor speed of $550 \mathrm{rpm}$, the main transmission should reduce the speed by $1: 3.5$ which will reduce the rotor speed to $\mathbf{5 2 9 - 5 8 8}[\mathrm{rpm}]$ and increase the output torque to $\mathbf{8 8 4 , 5 2}[\mathrm{Nm}]$.

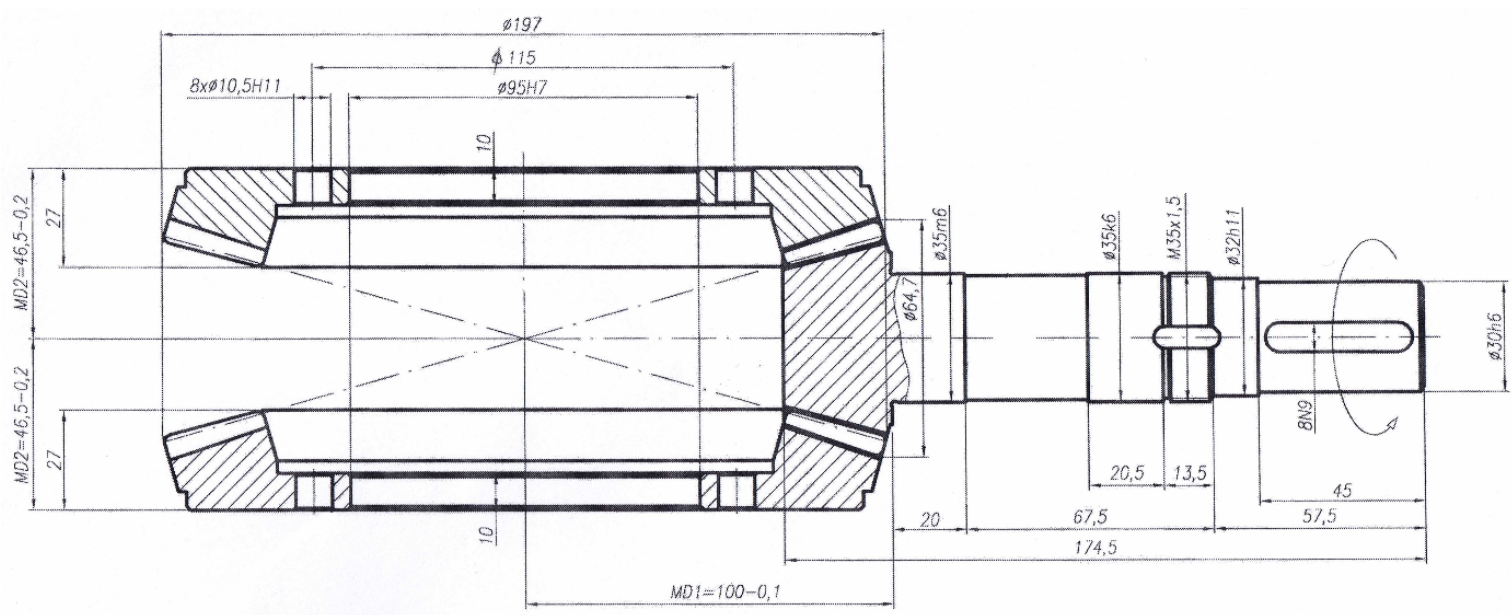

Figure 5. Set of gears [Own elaboration]

Bearing in mind the values of moments and input speeds, it is possible to calculate a set of gears that will perform the work of the transmission. The numerical analysis was carried out on the basis of the input data and the set of cooperating gears was obtained (Fig. 5.) The both gears are made of 16HG steel, hardened to 58-62 HRC hardness. Geometric and material conditions allow the transfer of a torque of $265[\mathrm{Nm}]$ at the input of the transmission, so the set of gears meets the assumed $252.72[\mathrm{Nm}]$.

The use of a gear system (Fig. 5.) in which one works over and the other under the propulsor gear allows the introduction of one direction of rotation on the propulsor and obtaining different directions of rotation on both cooperating gears. It should also be noted that the direction of rotation of the propulsor depends on the direction of inclination of the tooth line because the maximum torque transmitted by such a bearing assembly is not the same for both directions of rotation. 


\subsection{Gear housing}

After obtaining all the necessary data in the form of geometry of the gears and mechanical loads that the rotor generates during operation, it is possible to determine the geometry of the gear housing and the elements cooperating with it.

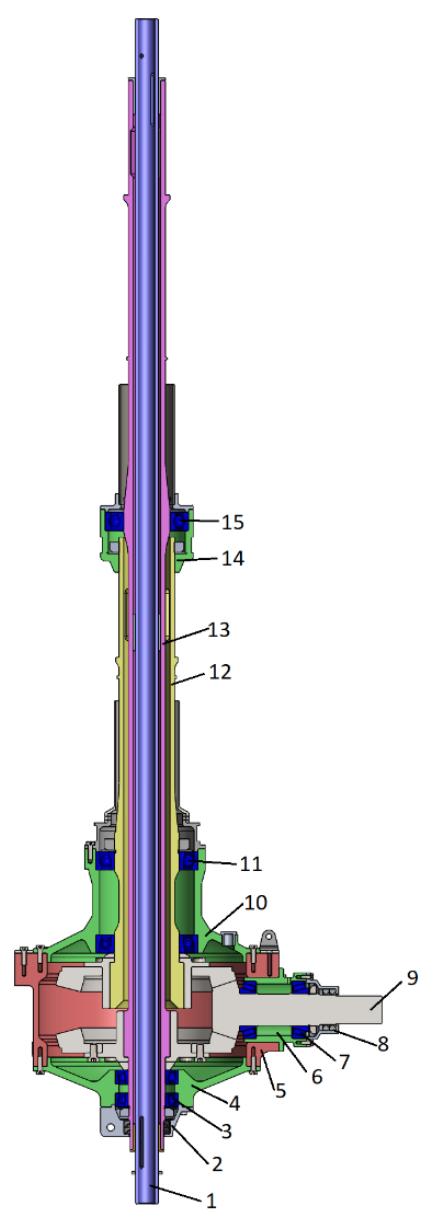

Figure 6. Main transmission; 1-central push rod; 2- bottom seal; 3-bearing assembly of the upper rotor; 4-lower cover; 5-gear housing; 6-bearing housing; 7-bearing assembly of the propulsor; 8-top seal; 9-propulsor; 10-top cover; 11-lower rotor bearing assembly; 12-bottom rotor shaft; 13-upper rotor shaft; 14-bearing housing for both shafts; 15-bearing assembly for joint shaft bearings [Own elaboration]

The torque from the engine is transmitted through the propoulsor (Fig.6 $\{9\}$ ) to the main transmissions gearwheels that are connected via groove with the bottom and upper rotor shafts (Fig. $6\{12,13\}$ ). Because the transmission gearwheels are over and beneath the propulsor rotating it in one direction makes the rotor shafts rotate in opposite directions. Inside the upper rotor shaft there is a central push rod (Fig. $6\{1\}$ ) that rotates together with the upper shaft. All the shafts are supported by bearings that connect them with the transmission housing. The Upper rotor shaft is supported by two angular ball 
bearings (Fig. $6\{3\}$ ) from the bottom and one ball bearing (Fig. $6\{15\}$ ) from top. The top support is connected via housing (Fig. $6\{14\}$ ) with the bottom rotor shaft. The bottom rotor shaft is supported by two angular ball bearings (Fig. $6\{11\}$ ) that connect it with the top cover of the gear box (Fig. $6\{10\}$ ). The propulsor is also supported by two angular tapper bearings (Fig. $6\{17\}$ ) that connect it with the bearing housing of the gearbox (Fig. $6\{6\}$ ). All shafts that come out of the gearbox are sealed by rubber seals (Fig. $6\{2,8\}$ ) that allow to keep the gearbox lubricant inn while the shafts and propulsor are rotating.

\subsection{Rotor hubs}

Having mass and geometric data for the blades we can start the process of rotor design. Due to the design assumptions, it is a rigid rotor with swivel joints for blade pitch changes. Aerodynamic analysis (rotational speed of the rotor) allows estimation of forces acting on the rotor arm.

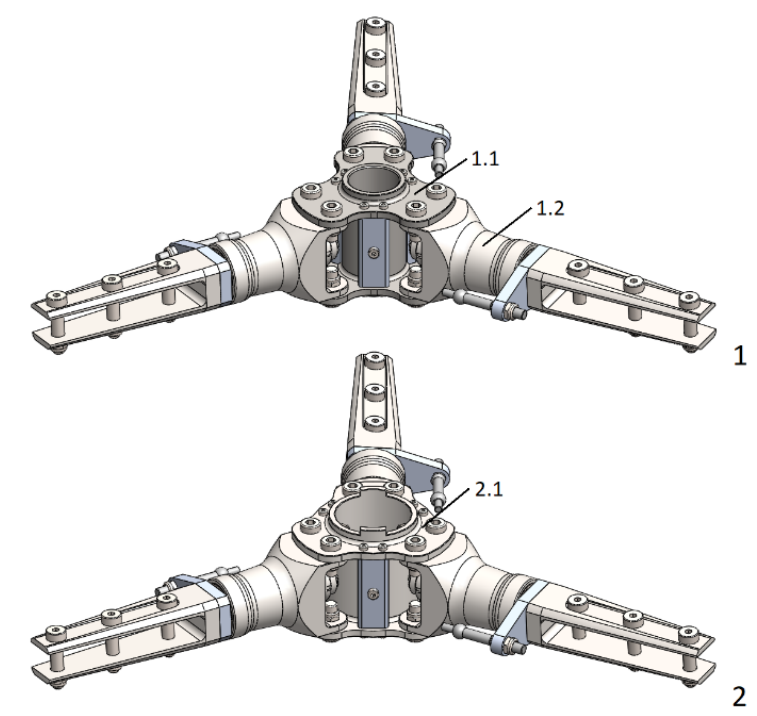

Figure 7. Coaxial rotors; 1-upper rotor hub; 1.1-upper central hub; 1.2-rotor arm; 2-lower rotor hub; 2.1-lower central hub [Own elaboration]

It is necessary to ensure the same diameter of both rotors in order not to regulate the various moments of drag with different balancing of the blades of both rotors. For economic reasons (manufacturing costs), all arms of both rotors are the same (Fig. $7\{1 ; 2\}$ ). In order to maintain the same diameter, only the hubs are modified (Fig. $7\{1.1 ; 2.1\}$ ).

The rotor arm consists out of the blade holder (Fig.8.\{1\}) that is attached via a set of ball bearings to the bearing housing (Fig. $8\{4\}$ ). The housing is connected thru four screws to the central hub (Fig. $8\{5\}$ ). The torque from the rotor shaft is transmitted to the rotor hub via three prismatic grooves (Fig. $8\{9\}$ ). The arm utilizes two bearings, a bigger tapered roller bearing (Fig. $8\{7\}$ ) whose role is to transfer the centrifugal force generated by the rotating blade mounted in the blade holder and the second tapered ball bearing (Fig.8. $\{6\}$ ) that makes an $\mathrm{X}$ type mounting arrangement that provides increased axial and radial load carrying capacity for the blade holder. The arm contains a pusher arm (Fig. $8\{2\}$ ) to which are connected the pushing rods of the control system via the pusher arm bolt (Fig. $8\{3\}$ ). 

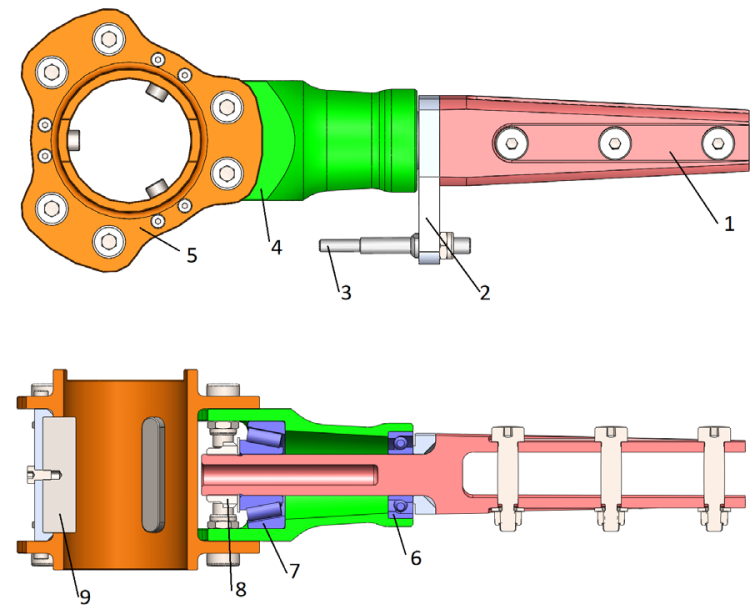

Figure 8. Rotor arm; 1-blade holder; 2- pusher arm; 3- pusher arm bolt; 4- bearing housing; 5-central hub; 6-tapered ball bearing; 7-tapered roller bearing; 8-bearing nut; 9- prismatic groove [Own elaboration]

\section{MECHANICAL CONTROL SYSTEM}

The change in collective pitch and cyclic pitch of the rotor system is carried out by means of a mechanical control system consisting of: lower swashplate, upper swashplate, drivers, disc pushers, central differential pusher, central pusher mixer (Fig. 9.)

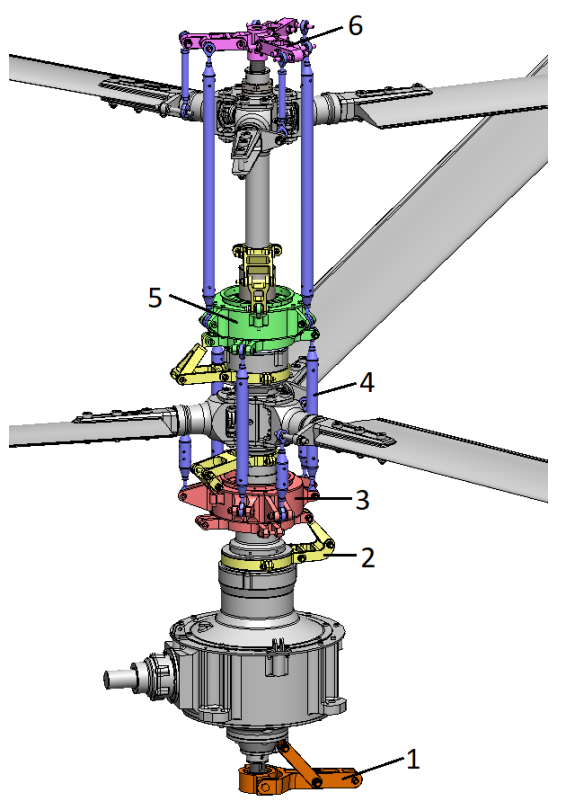

Figure 9. Mechanical control system; 1-Central differential pusher; 2- Carriages; 3-Lower swashplate; 4- swashplate pushers; 5-upper swashplate; 6-Mixer of the central pusher [Own elaboration] 
According to the aerodynamic analysis, the system should ensure the possibility of changing the angle of rotation of the feathering hinge in the range from $0-17$ degrees.

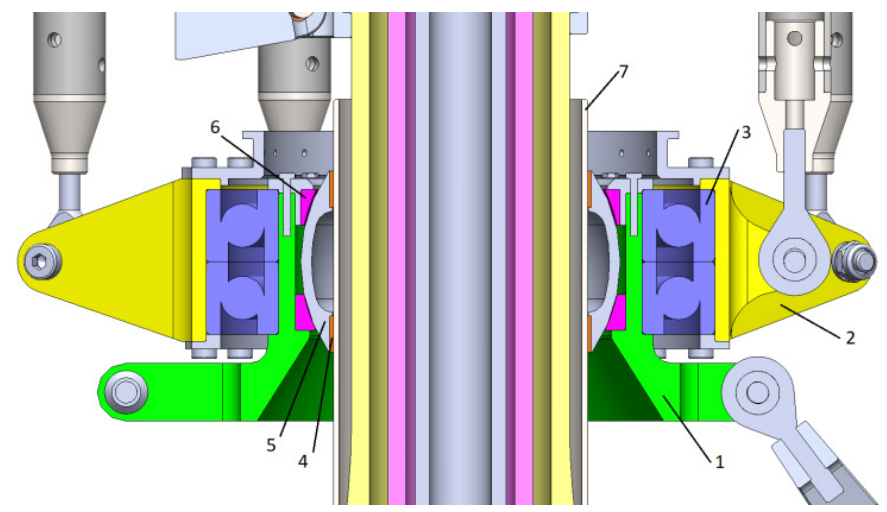

Figure 10. Swashplate design; 1-non-rotating part of the swashplate; 2-rotating part of the swash plate; 3-tapered ball bearing set; 4-linear slider; 5- swashplate ball; 6-teflon sliders; 7- sliding sleeve [Own elaboration]

The swash plate consists of a non-rotating part (Fig. $10\{1\}$ ) connected to the control system pushers for the lower swashplate and connected to the rotating part of the lower swashplate for the upper swashplate. The non-rotating parts of the lower swash plate is connected to the gearbox cover via carriage and the non-rotating part of the upper swashplate is connected via carriages to the lower rotor hub shaft making it rotate with the lower shaft. To the non-rotating part there is connected the rotating part (Fig. $10\{2\}$ ) via set of tapered ball bearing enabling it to rotate independently from the non-rotating part. The rotating part of the lower swashplate is connected via pushers with the lower rotor pusher arms and the upper swashplate non-rotating part, it is also connected via carriage with the lower rotor shaft making it rotate together with the shaft. The rotating part of the upper swashplate is connected via pushers to the mixer of the central pusher (Fig. $10\{6\}$ ), it is also connected via carriage with the upper rotor shaft making it rotate together with the shaft. The non-rotating part is placed on a swhashplate ball (Fig. $10\{5\}$ ) via teflon sliders (Fig. $10\{6\}$ ) giving the possibility to tilt the whole swashplate in any direction to a certain degree (in this case +- 20 degrees). The swashplate ball is mounted onto a sliding sleeve (Fig. $10\{7\}$ ) via linear sliders (Fig. $10\{4\}$ ) that provide the possibility to move the swashplate up and down along the axis of the rotor shafts.

The control signal is transferred from three actuators to the non-rotating part of the lower swashplate making it possible to tilt in any direction and to move it up and down. Changing the position of the lower swashplate causes the same position changes to the upper swashplate because they are connected via swashplate pushers (Fig. 9 \{4\}). Changing the position of the lower swashplate has an direct effect on the feathering hinges of the lower rotor hub because they are connected to the rotating part of the lower swashplate directly by the pushers. Changing the position of the upper shwashplate has an indirect effect on the feathering hinges of the upper rotor hub because the rotating part of the upper swash plate is connected to the feathering hinges via the mixer of the central pusher (Fig. $9\{6\}$ ). The mixer is connected to the central differential pusher and can move up and down, depending on the central pusher extraction the collective rotor pitch of the upper rotor can be changed without affecting the pitch on the lower rotor making the rotors generate different torques. 


\section{NUMERICAL ANALYSIS OF COMPONENTS}

Having the geometric data of the entire rotor system and specific forces acting on the system during operation, it is possible to perform FEA analysis to validate the correctness of the designed elements, for the purpose of this article the hover state was taken for the analysis.

\subsection{Numerical analysis of the gearbox body}

The analysis object is a gear housing assembly consisting of three elements: gear housing (Fig. $6\{5\}$ ), the top cover (Fig. $6\{10\}$ ) and the bottom cover (Fig. $6\{4\}$ ) connected together by means of M4 bolts. The housing elements will be made of $2024 \mathrm{~T} 4$ aluminum alloy. The loads of the housing resulting from the loading of the rotors were applied in the form of concentrated forces to the beam elements imaging the shafts (Fig. 11).

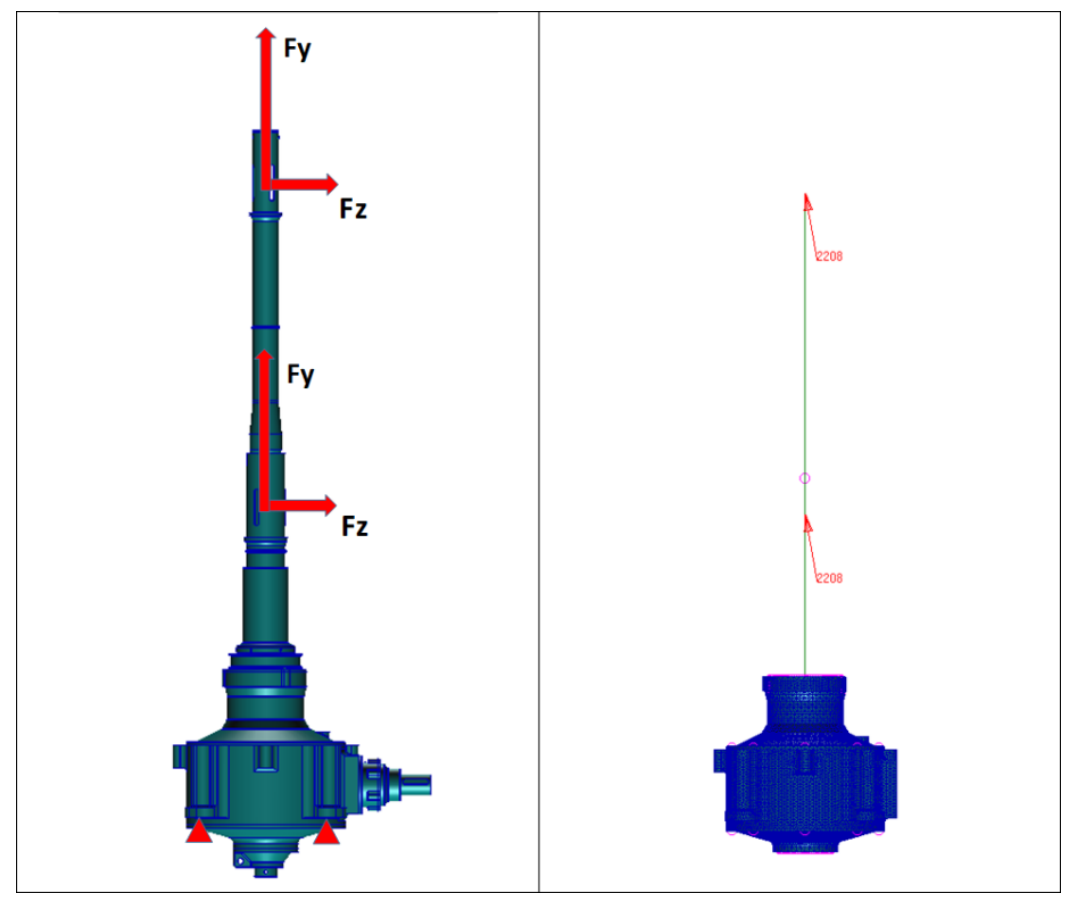

Figure 11. Loads and boundary conditions for the housing model, on the right MES model with beam elements reflecting the shafts [Sebastian Szałkowski, 2016]

For calculation purposes the loads was assumed for a hover state in the form of two forces applied to the shafts at the rotor attachment points with the value of $2208 \mathrm{~N}(225 \mathrm{~kg})$ because the overall takeoff mass of the unit should be not higher than $450 \mathrm{~kg}$. The calculations were made for two cases.

- Case 1: forces acting along the shaft axis $\left(\mathrm{F}_{\mathrm{y}}=\mathbf{2 2 0 8} \mathrm{N}, \mathrm{F}_{\mathrm{z}}=\mathbf{0} \mathrm{N}\right)$

- Case 2: forces acting at a 10 degree angle to the shaft axis $\left(F_{y}=2174.5 \mathrm{~N}, F_{z}=-383.4 \mathrm{~N}\right)$ 
Table 4. List of maximum stresses and displacements for case No. 1 [Sebastian Szałkowski, 2016]

\begin{tabular}{|l|c|c|c|}
\hline Element name & $\begin{array}{c}\text { Max reduced tension } \\
\sigma_{\text {red }} \\
{[\mathrm{MPa}]}\end{array}$ & $\begin{array}{c}\text { Max displacement. } \\
\mathrm{u}_{\mathrm{y}} \\
{[\mathrm{mm}]}\end{array}$ & $\begin{array}{c}\text { Max displacement. } \\
\mathrm{u}_{\mathrm{z}} \\
{[\mathrm{mm}]}\end{array}$ \\
\hline Top cover & 22.7 & 0.02 & 0.01 \\
\hline Gear housing & 12.2 & 0.004 & 0.002 \\
\hline Bottom cover & $\mathbf{3 1 . 6}$ & 0.04 & -0.01 \\
\hline Short shaft & 2.6 & 0.00 & 0.02 \\
\hline Long shaft & 4.1 & $\mathbf{0 . 0 6}$ & 0.00 \\
\hline
\end{tabular}
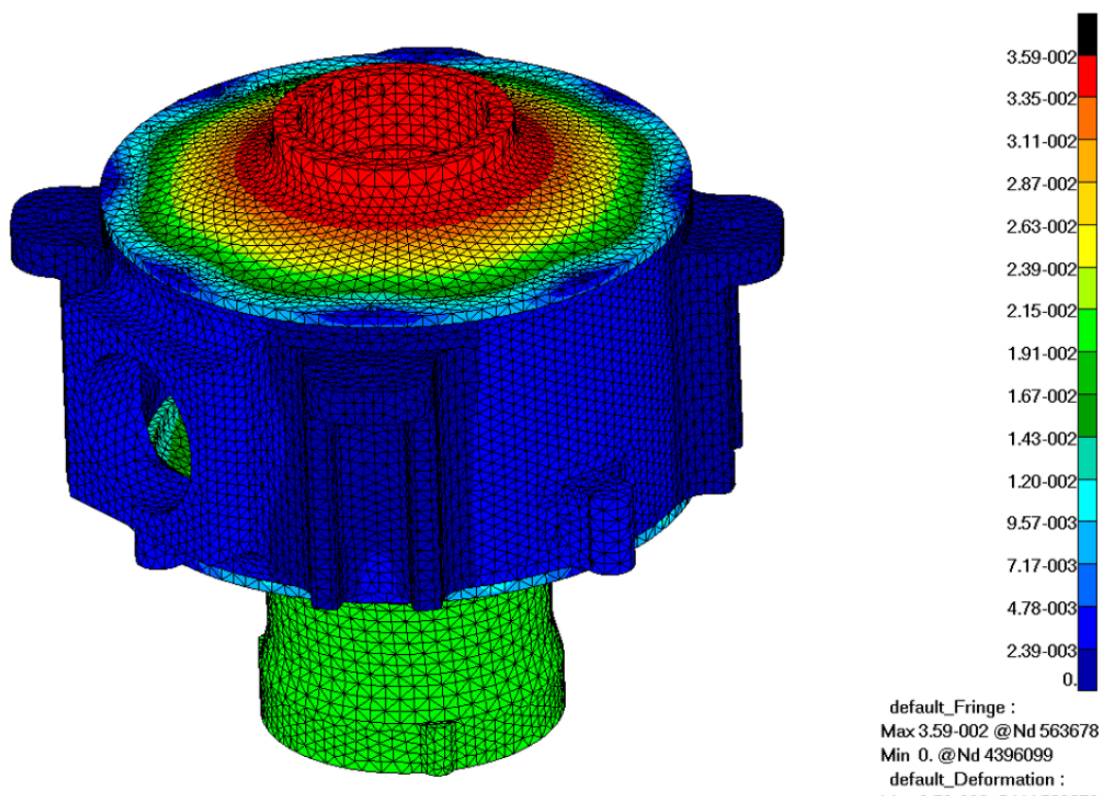

default_Fringe :

Max3.59-002@Nd563678 Min 0.@Nd 4396099

Figure 12. Displacements of the housing assembly for case No. 1 [Sebastian Szałkowski, 2016]

Table 5. List of maximum stresses and displacements for case No. 2 [Sebastian Szałkowski, 2016]

\begin{tabular}{|l|c|c|c|}
\hline Element name & $\begin{array}{c}\text { Max reduced tension } \\
\sigma_{\text {red }} \\
{[\mathrm{MPa}]}\end{array}$ & $\begin{array}{c}\text { Max displacement. } \\
\mathrm{u}_{\mathrm{y}} \\
{[\mathrm{mm}]}\end{array}$ & $\begin{array}{c}\text { Max displacement. } \\
\mathrm{u}_{\mathrm{z}} \\
{[\mathrm{mm}]}\end{array}$ \\
\hline Top cover & $\mathbf{9 2 . 4}$ & 0.07 & -0.07 \\
\hline Gear housing & 27.4 & 0.01 & -0.01 \\
\hline Bottom cover & 32.8 & 0.04 & 0.02 \\
\hline Short shaft & 31.8 & 0.03 & -0.53 \\
\hline Long shaft & 38.6 & 0.05 & $\mathbf{- 1 . 8 7}$ \\
\hline
\end{tabular}



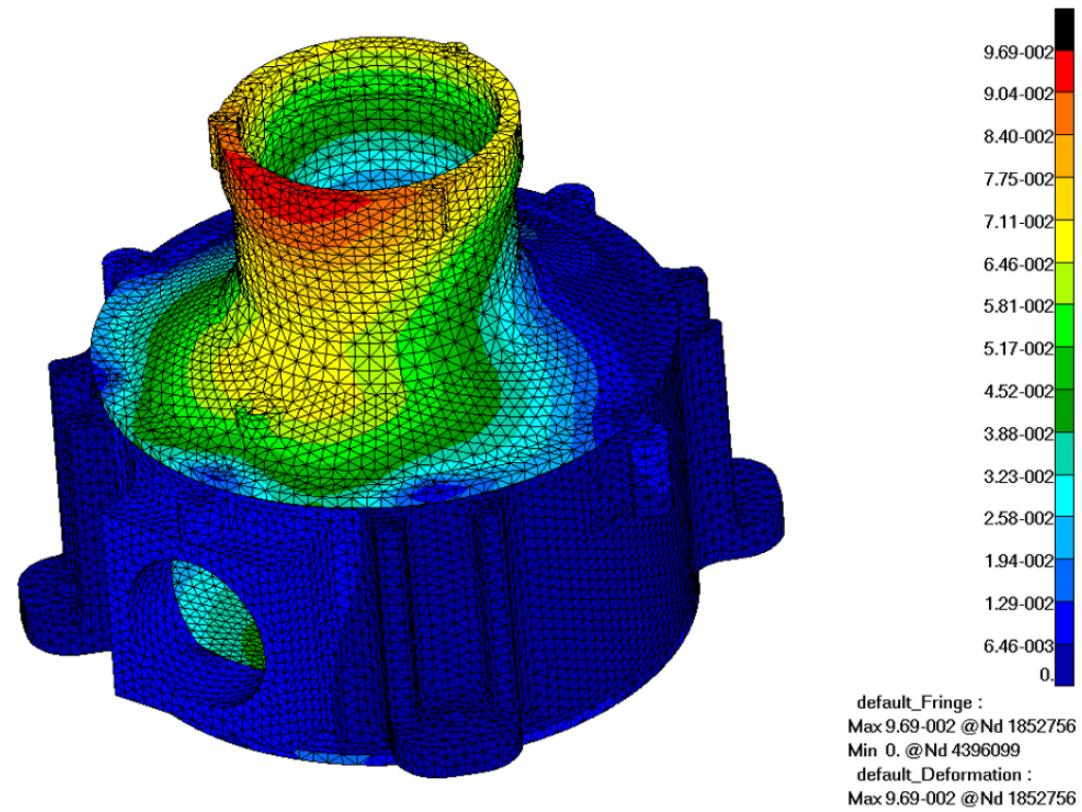

Figure 13. Displacements of the housing assembly for case No. 2 [Sebastian Szałkowski, 2016]

The gear housing has sufficient strength for defined loads. The maximum reduced stresses (92.4 MPa) in the top cover calculated for case No. 2 are much lower than the yield stress $\mathrm{Re}=260 \mathrm{MPa}$ for material $2024 \mathrm{~T} 4$ in the thickness range up to $12.7 \mathrm{~mm}$. The strength reserve is in this case is 2.8 . The maximum deflection of the long shaft end towards $\mathrm{z}$ (perpendicular to the shaft axis) for Case No. 2 is $1.87 \mathrm{~mm}$. The displacement of the long shaft with respect to the short shaft on the section along the short shaft is less than $0.2 \mathrm{~mm}$, which will not bring both shafts together (the gap between the shafts is $5 \mathrm{~mm}$ ).

\subsection{Numerical analysis of the rotor heads.}

- Central hub

The calculations were carried out for $30 \mathrm{HGSA}$ steel with Rm min =1100 [MPa], E = $210000 \mathrm{MPa}$. The part was loaded with vertical force (lifting force) $\mathrm{F}_{\mathrm{N}}=1000 \mathrm{~N}$ and horizontal (centrifugal force) $\mathrm{F}_{\mathrm{O}}=42900 \mathrm{~N}$. The load was applied at a distance of $1500 \mathrm{~mm}$ from the central blade attachment hole. The centrifugal force was determinated based on the estimated rotor blade mass (about $6 \mathrm{~kg}$ ), the position of the center of mas (about $1600 \mathrm{~mm}$ from the rotation axis) and the rotor nominal speed (about $550 \mathrm{rpm}$ ). The lifting force was determinated by the overall mass of the designed unit ( $450 \mathrm{~kg}$ per rotor, $250 \mathrm{~kg}$ per rotor hub, $83 \mathrm{~kg}$ per blade, + about 20\% strength reserve) 

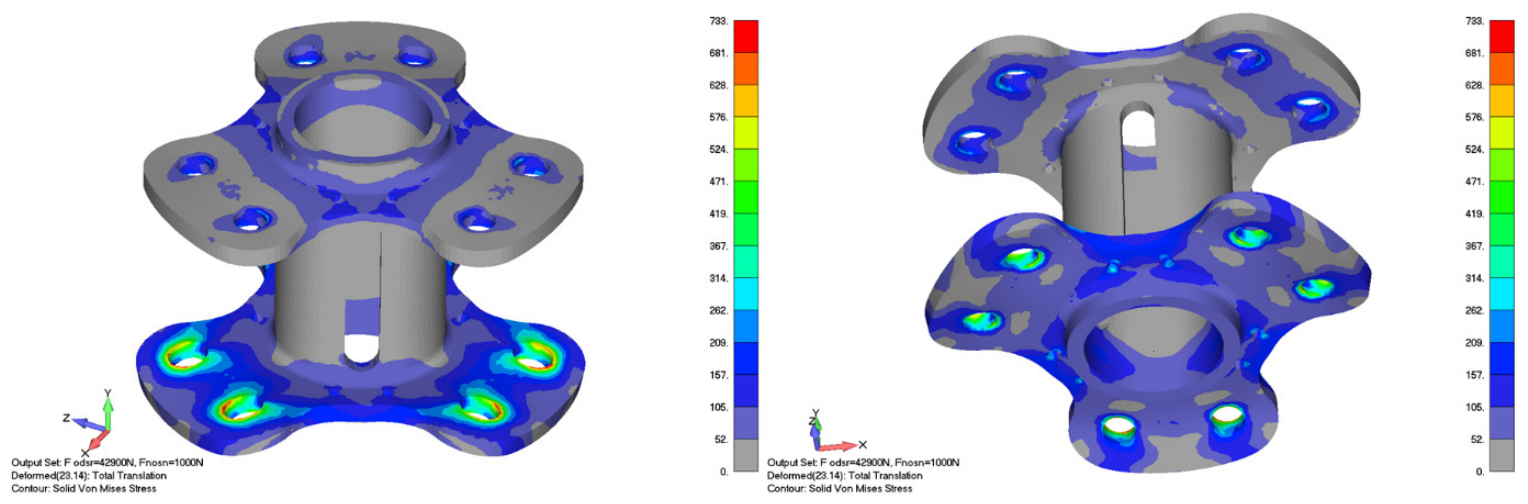

Figure 14. Reduced stress for the upper hub. [Sebastian Szałkowski, 2016]
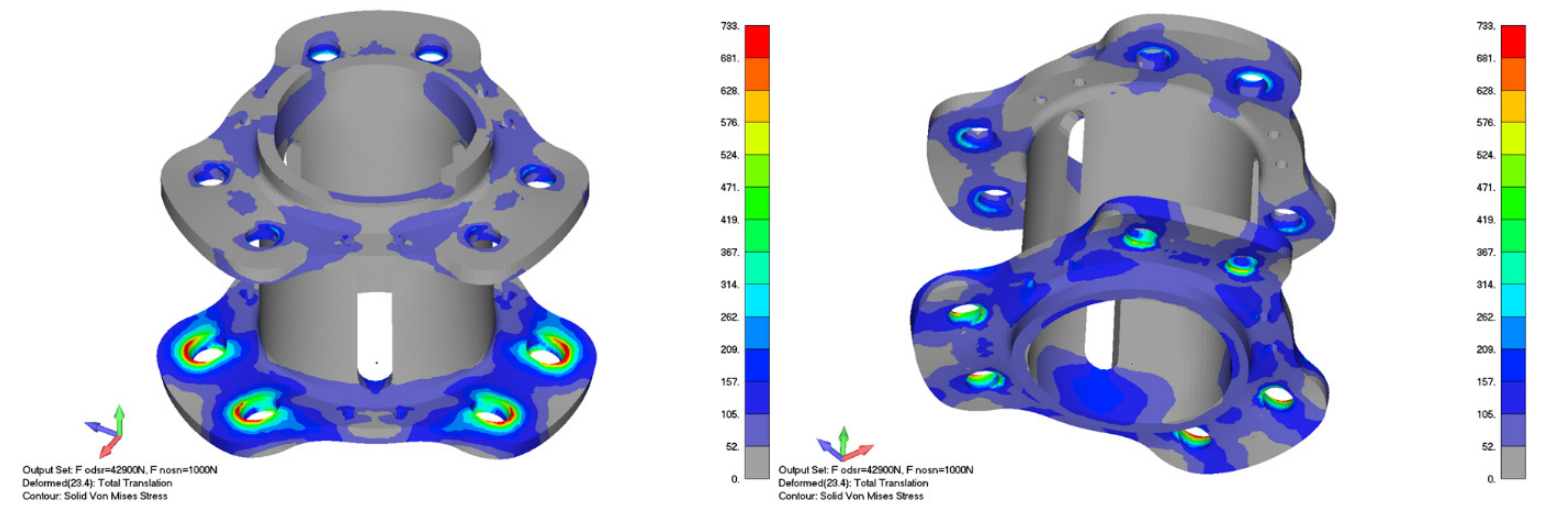

Figure 15. Reduced stress for the lower hub [Sebastian Szałkowski, 2016]

The maximum stresses do not exceed $350 \mathrm{MPa}$ for the hub fixing the upper heads and $250 \mathrm{MPa}$ for the hub fixing the lower head, therefore the condition ored $\max \leq \mathrm{Rm} \min / 1.5$ was met. Concentrations of stresses at the edges of the mounting holes of the analyzed part to the sleeve result from the contact and discrete representation of the curved surface.

- Rotor arm bearing housing

The calculations were carried out for $30 \mathrm{HGSA}$ steel with $\mathrm{Rm} \min =1100[\mathrm{MPa}], \mathrm{E}=210000 \mathrm{MPa}$. The part was loaded with vertical force (lifting force) $\mathrm{F}_{\mathrm{N}}=1000 \mathrm{~N}$ and horizontal (centrifugal force) $\mathrm{F}_{\mathrm{O}}=42900 \mathrm{~N}$. The load was applied at a distance of $1500 \mathrm{~mm}$ from the central blade attachment hole. The same loads applied like for the central hubs. 

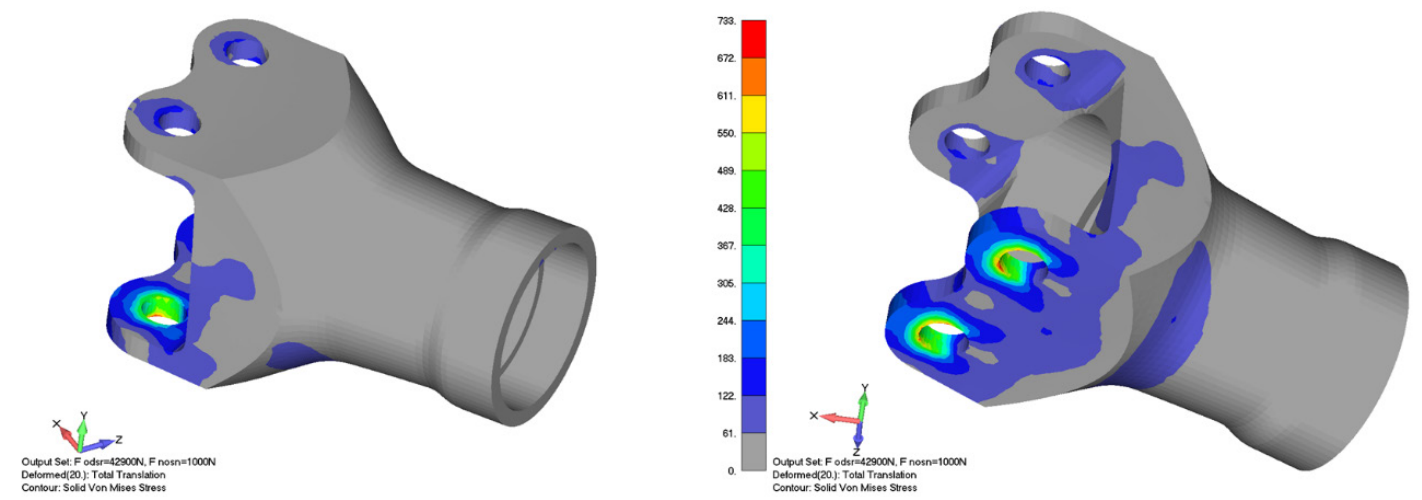

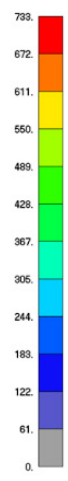

Figure 16. Reduced stress for the bearing housing [Sebastian Szałkowski, 2016]

Maximum stresses do not exceed $300 \mathrm{MPa}$, therefore the condition oredmax $\leq \mathrm{Rm}$ min / 1.5 was met. Concentrations of stresses at the edges of the mounting holes of the analyzed part to the sleeve result from the contact and discrete representation of the curved surface.

\section{- Holder fixing the blade}

The calculations were carried out for $30 \mathrm{HGSA}$ steel with Rm min = $1100[\mathrm{MPa}], \mathrm{E}=210000 \mathrm{MPa}$. The part was loaded with vertical force (lifting force) $\mathrm{F}_{\mathrm{N}}=1000 \mathrm{~N}$ and horizontal (centrifugal force) $\mathrm{F}_{\mathrm{O}}=42900 \mathrm{~N}$. The load was applied at a distance of $1500 \mathrm{~mm}$ from the central blade attachment hole. The same loads applied like for the central hubs.
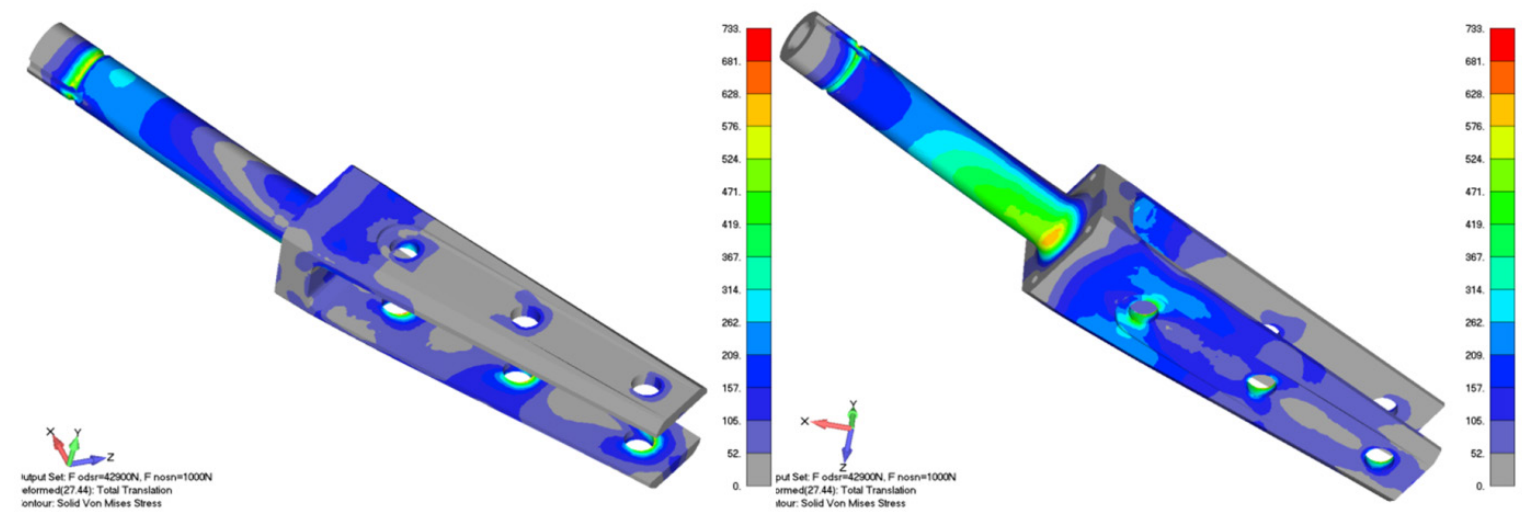

Figure 17. Reduced stress for the blade holder [Sebastian Szałkowski, 2016]

Maximum stresses do not exceed $633 \mathrm{MPa}$, therefore the condition ored $\max \leq \mathrm{Rm} \min / 1.5$ was met. 


\section{MACHINING AND ASSEMBLY OF ELEMENTS}

After numerical validation confirming the mechanical properties of the rotor, the process of preparation of the manufacturing documentation that will be used to make all of the rotor components takes place. Using CAD software the $3 \mathrm{~d}$ models were converted into $2 \mathrm{~d}$ technical drawings that were send to the manufacturers and based on them the final elements were made.

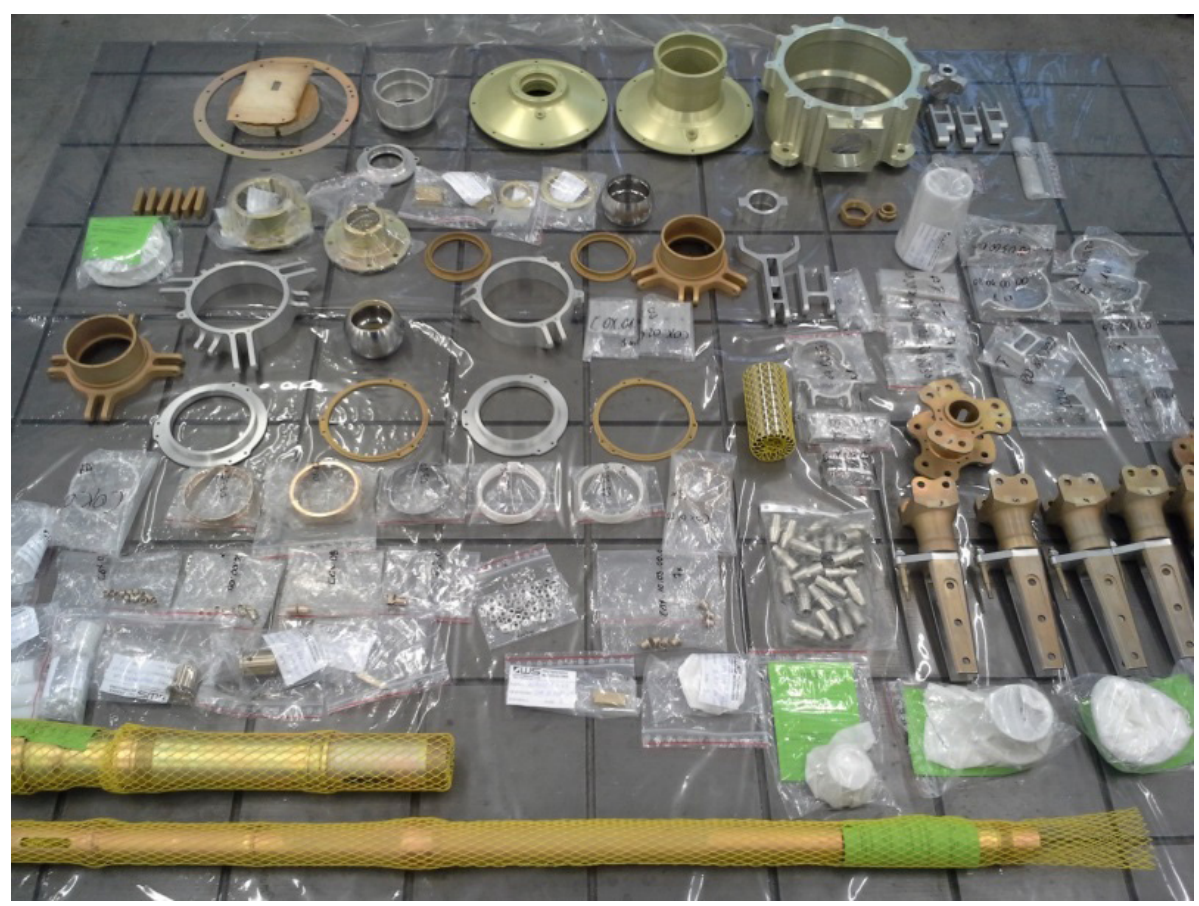

Figure 18. Parts of the rotor [Own elaboration]

All the aluminum parts were milled using 2024 T4 alloy with copper as the primary alloying element. It is used in applications requiring high strength to weight ratio, as well as good fatigue resistance. It is weldable only through friction welding, and has average machinability. The T4 state was chosen because of the solution treated process and naturally aging. Due to poor corrosion resistance of this material all the aluminum parts were anodized to prevent oxidation process.

All the steel parts were milled using 30 HGSA structural alloy steel for thermal improvement. This Highly hardenable steel, high wear resistance and durability, was designed for heavy-duty machines construction. Also used on riveted parts, for part with medium dimensions, which work up to a maximum temperature of $150-200{ }^{\circ} \mathrm{C}$. Typically used for elements up to $60 \mathrm{~mm}$, due to the preservation of suitable mechanical properties. The relevant parameters only appear after thermal treatment. The parts subjected to the highest load sucha as rotor hubs and rotor shafts were heat tempered to about $1100-1200[\mathrm{MPa}]$ the other were heat tempered to about 600-800 [MPa]. The steel componenets were cadium plated to prevent oxidation process. Both of the aforementioned materials were chosen thanks to their increased were resistance.

After the machined part delivery based on the assembly documentation, the entire rotor was assembled (Fig. 18). 


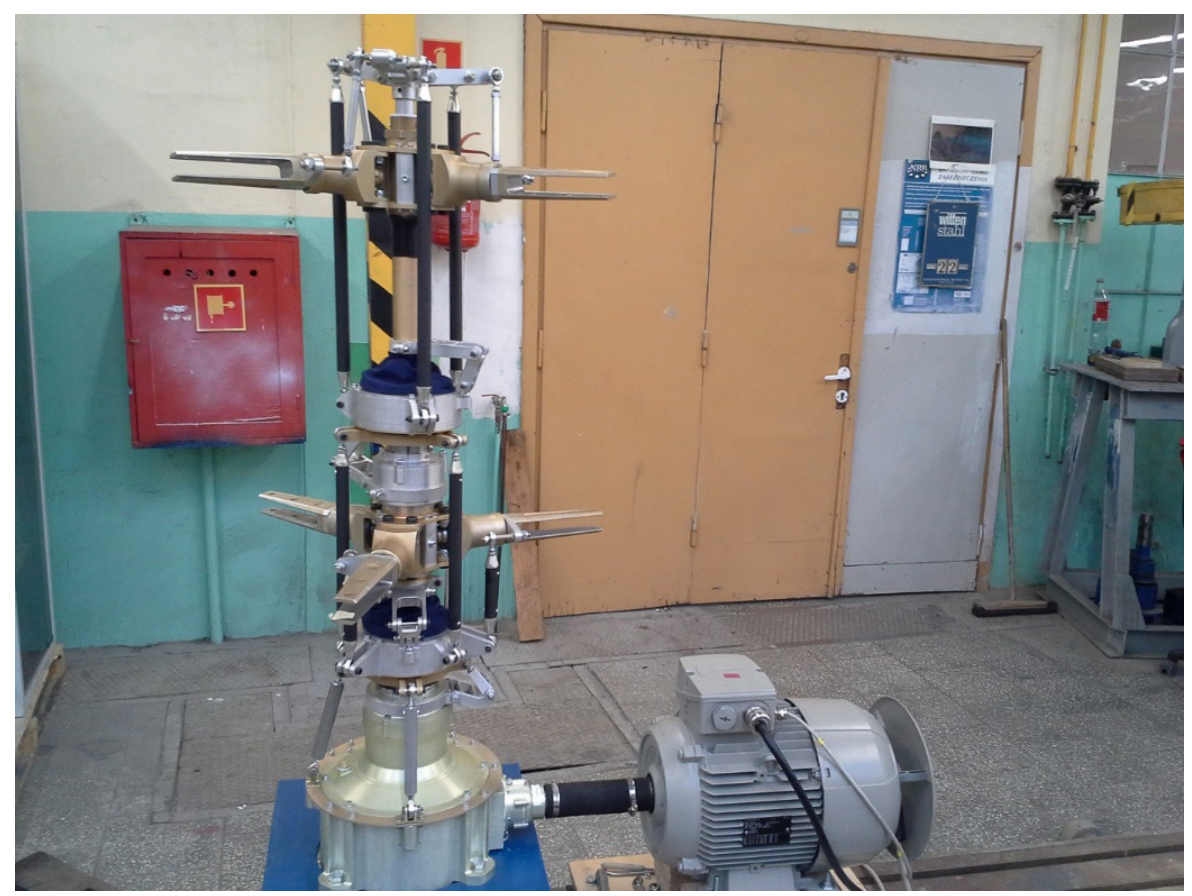

Figure 19. Coaxial rotor assembly [Own elaboration]

\section{CONCLUSIONS}

The process of mechanical analysis of a coaxial counter rotor presented in this article allows to quickly design and manufacture a rotor focused on the parameters that the designers wants to maximize (in this example cruising speed and payload).

After formulating the basic requirements for the rotor and designing a demonstrator it can be quickly manufactured and submitted to stand tests that allow to collect all the necessary measurement values such as natural frequencies, thrust force, brutal control, and progressive flight characteristics. That kind of data is very hard to predict using mathematical analysis. The collected measurement data of the real object allow for much better determination of further rotor development path than purely computational data adding more iteration tries of creating a rotor demonstrator in the same amount of time than a more computational approach.

The presented process is not limited to the concept of a coaxial rotor, it can be used to design rotors in all systems.

\section{REFERENCES}

[1] Bratuchin, J.P., 1958, “Design and construction of helicopters” (in Polish: „Projektowanie i konstrukcja śmigłowców”), Państwowe Wydawnictwa Techniczne, Warsaw.

[2] Stanisławski, J., 2018, "Performance requirements and simulation of rotor operation for high-mountain rescue helicopter", Journal of KONES Powertrain and Transport, Vol. 25, No. 2.

[3] Aubry J.A., 1982, "Rotary-wing aircraft rotor having a compact articulated hub", US Patent 4361415. 
[4] Ferris, D.L., Rybicki, R.C., 1976, “Two-position helicopter main rotor”, US Patent 397249.

[5] “Skeldar V-150", https://pl.wikipedia.org/wiki/Skeldar_V-150, access: 17.10.2018.

[6] Devine, V., 2016, "Cypher ${ }^{\circledR}$ Unmanned Aerial Vehicle (UAV)", https://www.sikorskyarchives. com/CYPHER.php, access: 17.10.2018.

[7] “Sikorsky Cypher”, https://pl.wikipedia.org/wiki/Sikorsky_Cypher, access: 17.10.2018.

[8] Sabak, J., 2016, “Eurosatory 2016: Drone to suppress riots?”, (in Polish: „Eurosatory 2016: Dron do tłumienia zamieszek?”), http://www.defence24.pl/390650, eurosatory-2016-dron-do-tlumienia-zamieszek, access: 17.10.2018.

[9] “Aero Surveillance développe un drone destiné à la surveillance maritime", 2015, http://www. lemarin.fr/secteurs-activites/defense/22553-aero-surveillance-developpe-un-drone-destine-la-surveillance, access: 17.10.2018.

[10] "EADS Sharc", https://pl.wikipedia.org/wiki/EADS_Sharc, access: 17.10.2018.

[11] "HELICOPTER UAV / AERIAL PHOTOGRAPHY / INSPECTION / MAPPING", http:// www.directindustry.com/prod/swissdrones/product-181673-1790016.html, access: 17.10.2018.

[12] “SDO 50 V2", 2018, http://www.swissdrones.com/sdo-50/, access: 17.10.2018.

[13] Mortimer, G., "KOAXX-240 MKII - Ready For Vertical Take-off”, 2010, , https://www.suasnews. com/2010/09/koax-x-240-mk-ii-\%E2\%80\%93-ready-for-vertical-take-of/, access: 17.10.2018.

[14] "V-200 SKELDAR UNMANNED, VERSATILE \& MISSION READY”, https://umsskeldar. aero/our-products/rpas-systems/v-200-skeldar/, access: 17.10.2018.

[15] "Camcopter S-100 unmanned air system", https://schiebel.net/products/camcopter-s-100/, access: 17.10.2018.

[16] "EHANG 184", http://www.ehang.com/ehang184/, access: 17.10.2018.

[17] "Sunward UAV”, 2018, https://en.wikipedia.org/wiki/Sunward_UAV, access: 17.10.2018.

[18] “Ka-137”, 2016, https://pl.wikipedia.org/wiki/Ka-137, access: 17.10.2018.

[19] Carey, B., 2014, "Beijing ZHZ Displays TD220 Unmanned Helicopter”, https://www.ainonline.com/ aviation-news/2014-02-12/beijing-zhz-displays-td220-unmanned-helicopter, access: 17.10.2018.

[20] Brzoska, Z., 1974, “Strength of materials” (in Polish: „Wytrzymałość materiałów”), PWN, Warsaw.

[21] Żurawski, R., Ulma, D., 2018, „Investigation of 'jump take-off possibility for the new concept of modern autogyro", $31^{\text {st }}$ Congress of the International Council of the Aeronautical Sciences

\section{PROCES KONSTRUKCYJNEJ ANALIZY MECHANICZNEJ WSPÓŁOSIOWEGO WIRNIKA PRZECIWBIEŻNEGO DO ZASTOSOWAŃ W JEDNOSTKACH ULTRALEKKICH}

\section{Streszczenie}

Elementem, który ma najwięlkszy wpływ na właściwości śmigłowca jest jego wirnik, dlatego bardzo ważnym czynnikiem jest określenie na wczesnych etapach procesu projektowania założeń, które wirnik powinien spełniać, aby wykonać misję, do której tworzy się projektowany śmigłowiec. Poniższy artykuł przedstawia proces analizy mechanicznej stosowany przez Instytut Lotnictwa do szybkiego opracowania 
prototypu współosiowego wirnika, stosowanego w ultralekkim bezzałogowym śmigłowcu, który ma potencjał do dalszego rozwoju w celu zmaksymalizowania jego parametrów lotu. W artykule opisano proces analizy wirnika ze względu na jego wykonalność w oparciu o komercyjnie dostępne rozwiązania, proces formułowania założeń dla całej konstrukcji, analizę MES części składowych wirnika prowadzące do powstania prototypu.

Słowa kluczowe: analiza wirnika, wirnik współosiowy, ultra lekki.

The work was carried out as part of the implementation of research project no. 21880 financed from statutory funds of the Institute of Aviation. 